Journat Engine

\title{
İnşaat projelerinde iş değişiklik emri takibi ve hak taleplerinin yönetimi üzerine bir vaka araştırması
}

\section{A case study on change order tracking and claim management in construction projects}

\author{
Betül TEMEL ${ }^{1}$, G. Emre GÜRCANLI ${ }^{2}$, Senem BILIIR MAHÇIÇEK ${ }^{3 *}$ \\ ${ }^{1}$ İstanbul Teknik Üniveristesi, İnşaat Mühendisliği Bölümü, temelbe@itu.edu.tr, Orcid No: 0000-0003-0472-3794 \\ 2 İstanbul Teknik Üniveristesi, İnşaat Mühendisliği Bölümü, gurcanlig @itu.edu.tr, Orcid No: 0000-0002-0807-2020 \\ ${ }^{3}$ İstanbul Teknik Üniveristesi, İnşaat Mühendisliği Bölümü, sbilir@itu.edu.tr, Orcid No: 0000-0001-6755-7960
}

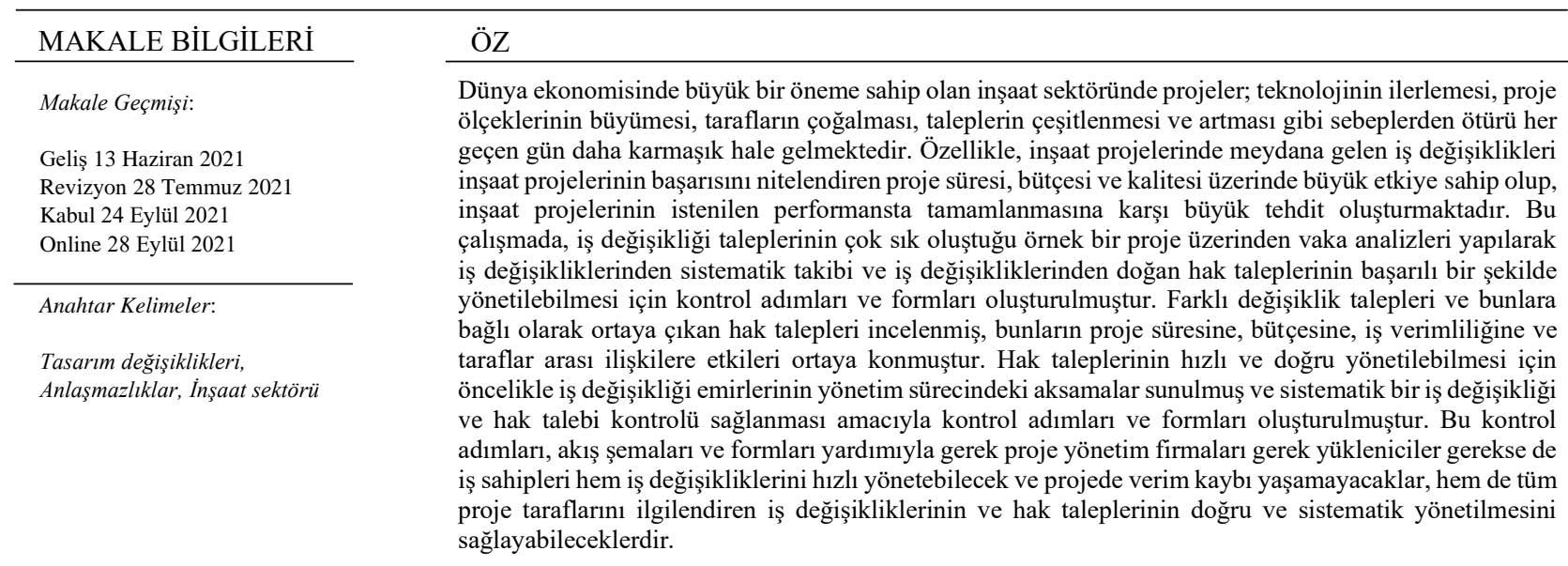

\begin{tabular}{|c|c|}
\hline ARTICLE INFO & ABSTRACT \\
\hline Article history: & $\begin{array}{l}\text { Construction projects have great importance in the world economy and they have been becoming more } \\
\text { complex every day due to the advancement of technology, the growth of the project scales, the proliferation }\end{array}$ \\
\hline Received 13 June 2021 & of the parties, the diversification and increase of the demands. In particular, changes in construction \\
\hline Received in revised form 28 July & projects throughout project duration due to change orders or other reasons have a great impact on the \\
\hline 2021 & project duration, budget and quality, which characterize the success of construction projects, and pose a \\
\hline Accepted 24 September 2021 & great threat to the completion of construction projects with the desired performance. Different change \\
\hline Available online 28 September 2021 & requests and the claims arising from them were examined, and their effects on the project duration, budget, \\
\hline Keywords: & $\begin{array}{l}\text { work efficiency and relations between the parties were revealed. Control steps and forms have been created } \\
\text { to ensure claim control. In this study, control steps, flowcharts and forms were created for the systematic }\end{array}$ \\
\hline Design changes, Disputes, & follow-up of job changes and the successful management of claims arising from job changes by conducting \\
\hline Construction Industry & case studies on a sample project where job change orders occur frequently. Different change orders and \\
\hline & $\begin{array}{l}\text { the claims arising from different types of change orders were examined, and their effects on the project } \\
\text { duration, budget, efficiency and relations between the parties were revealed. In order to manage claims }\end{array}$ \\
\hline & $\begin{array}{l}\text { quickly and accurately, the disruptions and problems in the claim management process due to change } \\
\text { orders were presented and control steps and forms were created in order to ensure a systematic job change }\end{array}$ \\
\hline & and claim control. By the aid of these control steps, flowcharts and forms, both project management \\
\hline Doi: $10.24012 /$ dumf.1002200 & $\begin{array}{l}\text { companies, contractors and owners will be able to manage job changes quickly, not to lose productivity in } \\
\text { the project, and to ensure correct and systematic management of business changes and claims that concern }\end{array}$ \\
\hline * Sorumlu Yazar & all project parties. \\
\hline
\end{tabular}




\section{Giriş}

Günümüze barajları, sanayisi, enerji tesisleri, yolları, hastaneleri, fabrikaları, altyapıları vb. yapıları ile birlikte ülkemizin gelişmekte olan bir ülke olduğunu düşündüğümüzde; gelişimin temel alt yapısını "'inşaat", sektörünün oluşturduğunu söyleyebiliriz. Ülkemizde inşaat sektörünün ekonomi içerisindeki başlı başına kendi payı \%8 civarındadır. İnşaat sektörü aynı zamanda doğrudan veya dolaylı olarak 200'ün üstünde farklı sektörlere istihdam sağlayarak ve katma değer yaratarak ' 'ekonominin kaldıracı' 'olma özelliğini de taşımaktadır ve bu sektörler de hesaba katılırsa ekonomi içerisindeki dolaylı yaklaşık payı \%30 bandinda olmaktadir [1].

İnşaat sektörü Türkiye'de ve Dünya'da ekonominin gelişmesine katkı sağlayan iş kollarının başında gelmesine rağmen ekonomideki iç ve dış hareketlenmelere paralel olarak en çok etkilenen sektörlerin başında gelmektedir. Ekonomik hareketlenmelerle birlikte jeopolitik ve siyasi riskler ve belirsizlikler de inşaat sektörüne olan güvenin azalmasına sebep olmaktadır. İnşaat projelerinin karmaşık ve kompleks bir yapısının olması, mekanik, elektrik, mimari ve inşai başta olmak üzere birçok disiplinin sürece dahil olması ve disiplinlerin birlikte çalışması gerekliliği projelerin bir bütün olarak ilerlemesini ve gruplar arasındaki koordinasyonun sağlanmasını zorlaştırmıştır. Disiplinlerin herhangi birinde meydana gelen bir değişiklik projenin tüm parçalarını büyük ölçüde etkileyebilmektedir. İnşaat projelerinde karşılaşılan 'İş değişiklikleri'”, projenin tipi, büyüklüğü, yapılış amacı ne olursa olsun inşaatın her evresinde ortaya çıkabilen ve tüm inşaat projelerinin maruz kaldığı kaçınılması mümkün olmayan ortak bir konudur [2]. Dünyada bu noktada oluşan boşluğun doldurulmasının gerekliliği, insanların kendilerini daha güvende hissedecek ortamda inşaat yatırımı yapmak istemeleri ve yatırımlarının istedikleri süre, kalite ve maliyette gerçekleştirilmesi talepleri Projelerin çok daha iyi yönetilmesi gerekliliğini doğurmuştur. Bu sebeple özellikle büyük, karmaşık ya da uluslararası projelerde firmalar proje yönetim şirketleri ile çalışma gereği duymaya başlamışlardır. Söz konusu projelerde ortaya çıkan iş değişikliklerinin proje kalitesi, projedeki işgücü verimliliği, projedeki taraflar arası ilişkiler üzerinde büyük etkilerinin olduğu da tespit edilmiştir. Bazı değişiklikler özellikle iş sahibine uzun vadede fayda sağlıyor gibi görünse de çoğu değişiklikler doğru yönetilmediği sürece muhtemel olasılıkla projenin süresinin uzamasına ve bütçesinin artmasına yol açan kötü sonuçları beraberinde getirir [3]. $\mathrm{Bu}$ çalışmada inşaat projeleri boyunca oluşan hak taleplerinin hızlı ve doğru yönetilebilmesi için tasarım öncesi dönemden başlayarak, inşaatın tamamlanması sonrasındaki dönemi de kapsayacak şekilde iş değişikliği emri yönetim sürecindeki aksamalar sunulmuş ve kontrol formları oluşturulmuştur Böylelikle, iş değişikliği kontrol süreçleri ve buna bağlı gelişen hak taleplerinin kontrol süreçlerinin tablo ile sistematik hale getirilmesi hedeflenmiştir.

\section{Yöntem}

$\mathrm{Bu}$ çalışmada öncelikle iş değişikliği emri ve hak talebi yönetimi kavramına yer verilmiştir. Ardından, iş değişikliği taleplerinin çok sık oluştuğu örnek proje hakkında genel bilgiler paylaşılmış, proje yönetimi ve organizasyon sunulmuştur. Ardından, örnek proje üzerinden vaka analizleri yapılmış ve projede yaşanan iş değişikliği taleplerinin proje bütçesine, süresine, iş gücü verimliliğine, son olarak da taraflar arasındaki ilişkiye etkisi detaylandırılmıştır. Oluşan iş değişikliği ve hak talebi yönetim sürecine yönelik kontrol tabloları hazırlanmıştır. Proje paydaşlarının tasarım öncesi dönemden başlayarak, inşaatın tamamlanması ve hatta proje teslimini de kapsayarak hangi aşamada hangi önlemi alması gerektiğinden bahsedilmiştir.

\section{İş Değişikliği Emri ve Hak Taleplerinin Yönetimi}

Baxendale ve Schofield (1996), '’iş değişikliğini”' Yüklenici ve İş Sahibi arasında imzalanan ana sözleşmenin kapsamında yapılan herhangi bir değişiklik olarak tanımlamışlardır [4]. Bu çalışmada da özellikle "iş sahibi” (owner) ifadesi kullanılacak olup, burada Construction Management Association of America (CMAA) tanımları baz alınacaktır [5]. Genel olarak iş değişikliğinin ortaya çıkması sonrasında taraflardan birinin iş değişikliğinin doğurduğu sonuçlara yönelik zararını karşılayacak nitelikte talepte bulunması literatürde ' 'hak talebi', olarak adlandırılmaktadır [6, 7, 8]. Hak talebi, yüklenicinin iş sahibinden, iş sahibinin yükleniciden veya mühendis/mimardan veya üçüncü kişilerin diğer taraflardan bulunması şeklinde 3 koldan gerçekleşebilir [9]. Yapılan literatür taramalarında iş değişikliğinin ortaya çıkması sonrasında yönetim sürecinin genel olarak beş aşamadan oluştuğu görülmüştür [10,11,12]. Bu aşamalar: (1) Değişiklik talebinin tespit edilmesi ve talebin Mühendis/Mimara iletilmesi, (2) Değişiklik talebinin haklılığının Mühendis/Mimar tarafından değerlendirilmesi, (3) Değişiklik talebi çalışmasının Mühendis/Mimar tarafından analiz edilmesi, (4) Değişiklik talebinin İş Sahibi ve Mühendis/Mimar tarafından onaylanması/reddi, (5) Onaylanan iş emri değişikliği çalışmasının resmiyet kazanması sonrası proje, belge ve dokümanların güncellenmesi, uygulanmaya başlaması şeklinde sıralanmıştır.

\section{Örnek Proje Hakkında Genel Bilgi}

Projenin oluşum süreci, kapsamı, tipi, proje sürecine dâhil olan taraflar, ihale süreci vb. konular, projede yaşanan değişikliklerin yatağını oluşturduğu için bu bölümde proje süreci ve kapsamı hakkında genel bilgiler verilmiştir. Söz konusu çalışma, başından sonuna kadar ilgili projede çalışan proje yöneticisi konumunda olan yazarlardan birisinin, günlük deneyimlerini kapsadığından, tüm süreçleri içermektedir. Öte yandan benzer projelerin de incelenmesi, çalışmanın değerini artıracaktır. Proje konusu, X üretim fabrikasının yapacağı üretim tesisi yatırımının inşaat sürecini kapsamaktadır. Proje kapsamı, üretim binası, yönetim binası ve yardımcı tesisler (güvenlik binaları, akü şarj yapıları, enerji merkezi binası, su deposu) ile birlikte yaklaşık $35.000 \mathrm{~m} 2$ ' dir. Proje bütçesi, sözleşme bedeli 49.500.000 TL'dir. İnşaat sürecinde yaşanan ek işler, kapsamdan çıkarılan işler, değişen işler ile birlikte 57.500.000 TL'ye inşaat tamamlanmıştır. Projenin başlangıç/bitiş tarihleri, tasarım başlangıç: 10.03.2017, inşaat başlangıç: 26.04.2018, inşaat bitiş: 30.06.2019'dur. Sözleşme tipi, anahtar teslimi götürü bedel esaslı sözleşmedir.

Proje Yönetim Firması yönettiği projelerde, genel olarak işin fikir proje aşamasında sürece dâhil olmaktadır. Proje Yönetim Firması bu proje için de benzer şekilde tasarımın fikir aşamasında sürece dâhil olmuş olup ihale sürecini de 
yürütmüştür. Kesin kabule kadar proje yönetim sürecinde bulunmuştur. Proje yönetimini ofis kadrosu ve şantiye kadrosu üzerinden yürütmüştür. Ancak ''yüklenici ile sözleşme imzalanması" aşamasında işveren tarafından süreç dışı bırakılmıştır. Örnek projeyi yöneten Proje Yönetim Firmasının dâhil olduğu ve yönettiği süreçleri gösteren akış diyagramı Şekil 1'de özetlenmiştir.

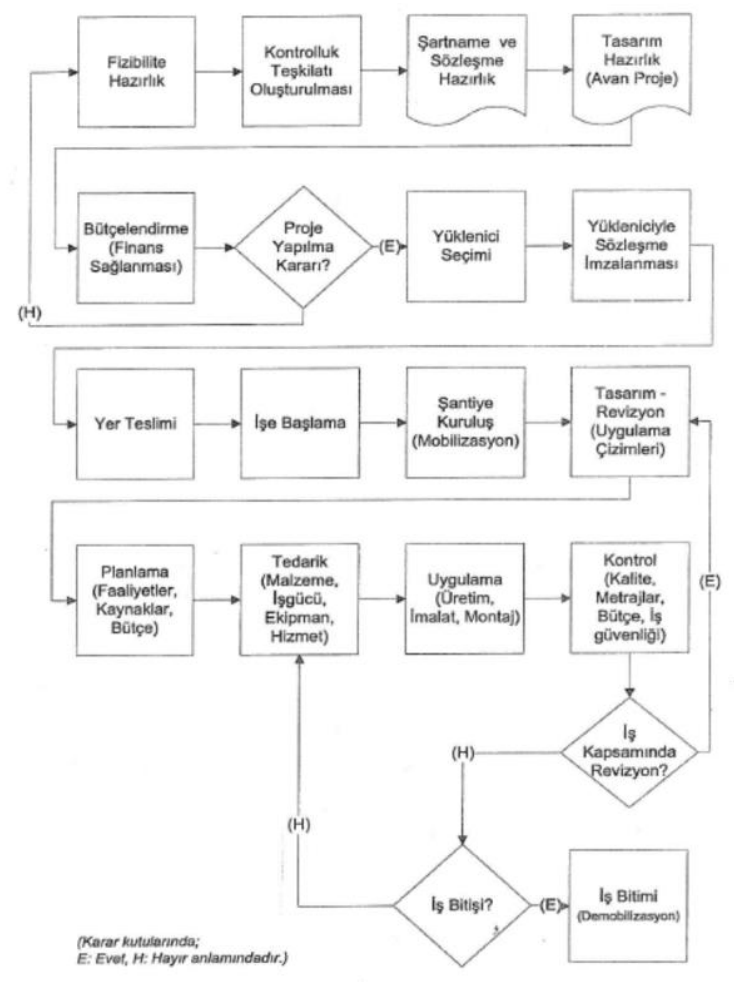

Şekil 1. Proje yönetim firmasının genel akış şeması.

İşveren ise birçok yöneticisi bulunan büyük ölçekli bir üretim firmasıdır. Firma, mevcut tesislerinin ihtiyaçlarını artık karşılamadığı gerekçesi ile yeni tesis yapılması girişiminde bulunmuştur. Bu kapsamda firma kendilerini temsilen projenin başına proje bazlı yöneticiler getirmiştir.

Yüklenici Firma, mekanik, elektrik ve diğer disiplinleri bünyesinde barındıran ana yüklenici sıfatındadır. Yüklenici firma, kendi bünyesinde barındırdığı birçok farklı gruplar ile çalıştığı projelerde çeşitli pozisyonlarda bulunmuş, işi yapabilecek yetkinlikte bir firmadır.

Tasarım firmasının yapısına ve sürece katkılarına bakacak olursak, tasarım gruplarının seçiminde koordinasyonun kolay ve bilgi akışının daha eksiksiz olması açısından mekanik, elektrik, statik, altyapı gruplarını bünyesinde barındıran ana bir Mimari Tasarım Grubu seçmiştir. Böylece uzun süredir birbirini tanıyan ve çalışma alışkanlığı olan farklı disiplinlerin arasında bilgi kopukluğu yaşanmasının önüne geçilmeye çalışılmıştır. İşverenin kararsızlıkları, zaman zaman kapsam değişikliğine gitmesi ve ihtiyaç planını bir türlü netleştirememesinden ötürü 6 ay olarak öngörülen örnek projenin tasarım süreci 1 yılı geçmiştir. Bu süreçte tamamlanan projenin İş Sahibi talebi ile iptal edilerek başka bir tasarıma gidilmesi ve projede yüzlerce revizyon talepleri yaşanmasından ötürü Tasarım Gruplarının çalışma istek ve performansları düşmüştür.
İnşaat sektöründe yaşanan iş değişikliklerini minimize edecek proje yönetim sistemi önerisi getirilebilmesi için öncelikle örnek projeyi yöneten Proje Yönetim Firmasının proje sürecindeki görev tanımı, iş kapsamı ve yönetim sistemi incelenmiştir. Örmek projeyi yöneten Proje Yönetim Firmasının proje süresince projedeki paydaşlar arasındaki rolü ve projedeki organizasyon yapısı Şekil 2'de gösterilmiştir.

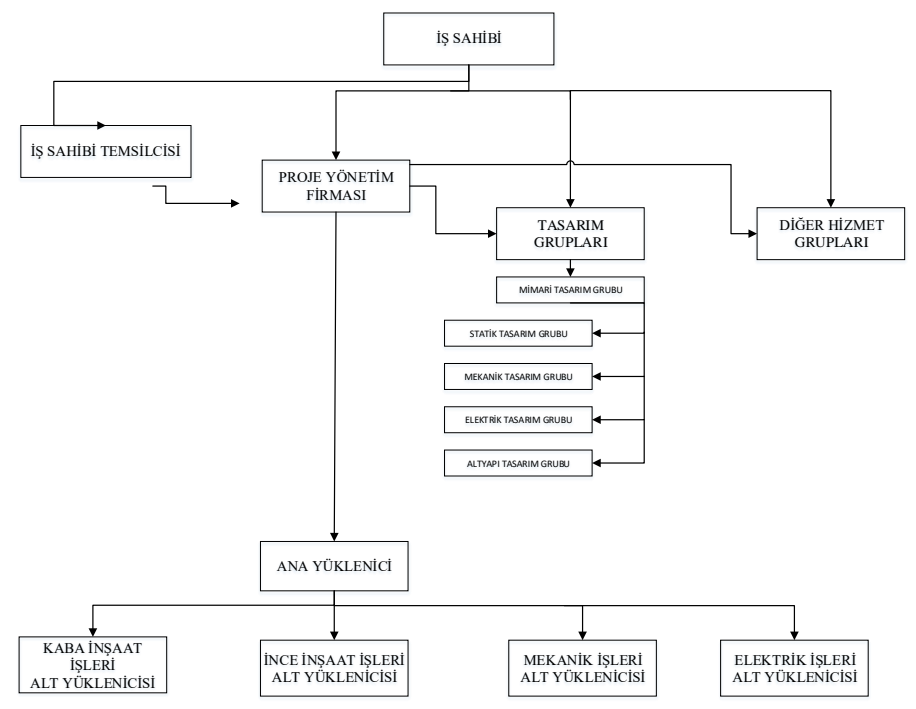

Şekil 2 :Proje yönetim firmasının projedeki rolü

\section{İncelenen Projede İş Değişikliği Emri Talepleri ve Yönetimi}

İş değişikliği emri taleplerinin ortaya çıkmasında, her projenin kendine özel bir sürü sebebi olmakla birlikte örnek projede yaşanan iş değişikliklerinin, değişiklik taleplerinin, krizlerin ve anlaşmazlıkların başlıca sebeplerini, etkilerini ve sebeplerin oluşmasına katkı sağlayan proje taraflarının belirlenebilmesi amacı ile 15 adet örnek olay üzerinden Vaka Analizi yapılmıştır. Ancak sayfa kısıtı nedeniyle tüm vaka analizleri makaleye eklenememiş ve örnek olması amacıyla 4 adet vaka analizi Tablo 1'de paylaşılmıştır.

\section{Bulgular}

\section{Örnek Projedeki İş Değişikliği Emri Taleplerinin Proje Üzerindeki Başlıca Etkileri}

Örnek proje bütünüyle incelendiğinde ilk dikkat çeken hususlar sırasıyla aşağıda sunulmuştur. İş veren vekillerinin (proje yöneticileri) sözleşme imzalanması sürecinde yüklenici ile birebir görüşmeler ve toplantılar yapması, görüşmelerde alınan kararların ve bu kararların sözleşme eki dokuman olarak imzalanması aşamasında bir kontrol mekanizması olan proje yönetim firmasının devre dışı bırakılmış olması inşaat aşamasında yaşanan birçok sıkıntının temelini oluşturmuştur. Yine söz konusu proje bazlı yöneticilerin, yeterli kapasitede ve yetkinlikte olmaması, süreçte baskın karakter olarak rol almaları ve kullanıcıları inşaat sürecinde dâhil etmeleri, iş verenin birçok karar verici yöneticisinin bulunması, her yöneticinin projenin farklı aşamalarında sürece dâhil olması, yine her yöneticinin farklı istekte bulunması ve sürekli iş değişikliğinin yaşanması, iş veren vekillerinin aralarında koordinasyon bulunmaması gibi sebepler, proje sürecinde bir çok iş değişikliği emrine dolayısı ile anlaşmazlıklara neden olmuştur. 
Yüklenicinin Proje Yönetim Firması ile çalışma uyumluluğu

konusunda pozitif ve negatif yanları olmuştur.

Tablo 1. Örnek projede oluşan hak talepleri vaka analizi örnekleri

Vaka 1

\begin{abstract}
Talep:
Yüklenici, sözleşme eki elektrik ve mekanik projelerin esas alındığı hesap raporlarının yanlış olduğunu, bu sebeple hesapların yeniden yapılarak elektrik projelerinin hazırlanması gerektiğini, bu revizyonlardan dolayı oluşan ilave bedelin de kendilerine ödenmesi gerektiğini beyan etmiştir. Talebini, sözleşme eki zeyilname olan "Sözleşme Dışı İşler" dokümanında yer alan maddeye atıfta bulunarak iletmiştir

Talebin

değerlendirilmesi:

İş Sahibi, Anahtar Teslimi İnşaat İşleri Sözleşme yapıldığını ileri sürerek gelen talebi reddetmiştir ve Proje Yönetim Firmasından değerlendirme istemiştir. Proje Yönetim Firması gelen talebi değerlendirmek için öncelikle ana sözleşmeyi ve eklerini incelemiştir. Ana sözleşmede Yükleniciyi niteleyen "basiretli tacir" sıfatı kullanılmasına rağmen, "Sözleşme Dışı İşler" listesinin ana sözleşmeden sonra imzalanmasından ötürü tüm taraflarca öncelikli kabul gördüğünü, sözleşme eki elektrik projelerindeki hesap raporunun yanlışlığından kaynaklı ortaya çıkan revizyon bedelinin Yükleniciye ek iş olarak verilmesi gerektiğini İş Sahibine iletmiştir. Talebin değerlendirilmesi sürecinde İş Sahibi konuyu kriz haline getirse de Yüklenicinin ilave bedel talebi sözleşme ekinde yazılan madde gereği kabul edilmiştir.
\end{abstract}

Talebi oluşturan Sözleşme ve eklerinin imzalanması sırasında Proje Yönetim Firmasının İş Sahibi tarafından sürece dâhil edilmemesinden dolayı sebepler: sözleşme ve eklerini detaylı kontrol edecek bir mekanizmanın olmaması, Sözleşme imzalanması sırasında İş Sahibinin yetkilendirdiği yöneticilerin imzaladıkları sözleşmeyi ve eklerini kontrol etmemiş olmaları,

Sözleşme ve sözleşme ekleri arasında uyumsuzlukların ve çakışmaların olması.

Etkileri:

Hesapların yeniden yapılması sonucunda projelerin revizyona uğraması ilave maliyet oluşmasına ve iş süresinin uzamasına sebep

olmuştur.

İş Sahibinin, Anahtar Teslimi İnşaat İşleri Sözleşmesi imzalandığını öne sürerek ve ana sözleşme imzalanmasından sonra imzaladığı "Sözleşme Dışı İşler" dokümanını göz ardı ederek ek bedel talebini kabul etmek istememesi taraflar arasındaki ilişkilerin gerilmesine sebep olmuştur.

Vaka 2

\begin{abstract}
Talep:
İ̧ Sahibi tasarım aşamasında proses ihtiyaçlarını göz ardı etmiş ve inşaat sürecine bırakmıştır. İnşaat sürecinde ise İş Sahibinden proses intiyaçlarına yönelik yoğun talepler gelmiş olup bu durum tasarımlarda revizyonlara ve iş değişikliklerine sebep olmuştur. Ayrıca bazı mahallerde proses ihtiyacı bilgisi Yükleniciye imalat tamamlandıktan sonra verilmiştir. Bu durum tamamlanan imalatlarda kırma ve dökme işlerinin yaşanmasına sebep olmuştur. Yüklenici, taleplerini iş emri değişikliği formu hazırlayarak Proje Yönetim Firmasına iletmiştir.
\end{abstract}

Talebin

İş Sahibinden gelen proses ihtiyaçlarından kaynaklı talepler, sözleşme eki projelerde olmamasından ötürü ilave iştir. değerlendirilmesi: $\quad$ Yüklenicinin bu başlık altındaki ilave iş talepleri değerlendirmeye alınmış ve gelen çalışmadaki metraj ve birim fiyatların Proje Yönetim Firması tarafından düzeltilmesi sonucu çıkan rakam üzerinde Yüklenici ile anlaşmaya varılmıştır

Talebi oluşturan İş Sahibinin proses ihtiyaçlarını tasarım aşamasında göz ardı etmesi ve netleştirmemesinden dolayı bu ihtiyaçların tasarımlara sebepler: $\quad$ işlenememesi ve inşaat gürecinde gündeme İş Sahibinin proses ihtiyaçlarını gündeme getirdiği sırada inşaat sürecindeki bir takım imalatların tamamlanmış olması, değişiklik talebi için geç kalınmış olmasından dolayı yapılan imalatların bozulması.

Etkileri:

Tasarımlarda revizyonlara ve yapılan imalatın bozulmasına sebep olmasından ötürü bütçe artışına ve iş süresinin uzamasına sebep olmuştur. İmalatı tamamlanan bölgeler için proses ihtiyaçlarının geç iletilmesinden dolayı yapılan imalatların kırılması ve bozulması gerekmiştir. Bu durum Yüklenicinin çalışma motivasyonunun düşmesine ve çalışma verimliliğinin azalmasına neden olmuştur.

Vaka 3

Talep:

Örnek proje yeşil bina sertifikasına sahiptir. Yeşil bina sertifikası alınması sürecinde projedeki malzeme seçimi, yapının harcayacağı enerji vb. konulardan puan toplanması, projedeki birçok malzeme seçimini etkilemiştir. Yüklenici bu konuyla ilgili birçok iş emri değişikliği talebinde bulunmuştur. Yeşil bina sertifika danışmanı tarafından enerji tasarrufu sağlayan aydınlatma otomasyonu ihale aşamasında talep edilmiş, ancak sözleşme imzalanması sırasında Yüklenicinin sözleşme eki olarak İ̧ Sahibine imzalattığı "Sözleşme Dışı İsler" başlığı altında yazan "Aydınlatma otomasyonu kapsam dışıdır." ibaresinden ötürü aydınlatma otomasyonu kapsam dışında bırakılmıştır

Talebin değerlendirilmesi:
Yüklenici, ihale aşamasında projenin yeşil bina sertifikası kapsamında olduğunu bilmesine rağmen İş Sahibine sözleşme imzalanması sırasında yeşil sertifika sürecinde kullanılması gereken malzemelere ilişkin teklifini vermediğini belirtilen maddelerin yer aldığı ve sözleşme eki olan 'Sözleşme Dışı İşler" listesini iletmiştir. Bu maddeler de İş Sahibi tarafından fark edilmeyerek imzalanmıştır. Yükleniciden gelen talepler projede revizyon olarak kabul edilmiş ve gelen çalışmalardaki metraj ve birim fiyatların Proje Yönetim Firması tarafından düzeltilmesi sonucu çıkan rakam üzerinde Yüklenici ile anlaşmaya varılmıştır. 
Talebi oluşturan Yeşil bina sertifika danışmanı tarafından tasarım aşamasında iletilen ve tasarıma yansıyan taleplerin İş Sahibi tarafından sebepler: imzalanan sözleşme ve eklerinde kapsam dışında bırakılmış olarak gözükmesi, Yeşil bina sertifika alınması kapsamındaki gereklilikler ile sözleşme eki dokumanlar arasında uyumsuzlukların olması, Yeşil bina sertifika alınması kapsamındaki gereklilikler ile sözleşme eki şartname ve birim fiyat tarifleri arasındaki uyumsuzlukların Proje Yönetim firması tarafından fark edilmemiş olması, Yeşil bina sertifikası alınması kapsamında danışmanlık veren firmanın ve tasarım gruplarının tasarım sürecinde koordineli olarak çalışmaması, danışmanın tasarımların gerekliliklere uyumluluğunu kontrol etmemesi, Tasarım Gruplarının bu gereklilikleri tasarımlarına eksik aktarması, Yeşil bina sertifika gerekliliklerinin bir kısmının tasarım evresinde değil, inşaat evresinde gündeme gelmesi, yeşil bina sertifika gereklilikleri ile tasarımlar arasında uyumsuzlukların oluşması.

Etkileri: Tasarımlarda revizyonlara sebep olması ve ek iş olmasından ötürü bütçe artışına sebep olmuştur. Tasarımlarda revizyonlara sebep olması ve ek iş olmasından ötürü iş süresinin uzamasına sebep olmuştur.

\section{Vaka 4}

\begin{tabular}{ll}
\hline Talep: & Yüklenici, proje kapsamında bulunan seksiyonel kapıları A marka olarak Proje Yönetim Firması onaya sunmuştur. Proje Yönetim \\
& Firması, sözleşme eki marka listesi, birim fiyat tarifleri, proje ve teknik şartnameleri kontrol ederek gerekli inceleme ve \\
& değerlendirmelerini yapmış ve olumlu görüşünü İş Sahibi onayına sunmuştur. İş Sahibi kendisine iletilen malzeme onay \\
& formunu incelediğinde seksiyonel kapı markası tercihinin A marka değil B marka olduğunu, sunulan malzeme markasının buna \\
& göre revize edilip tekrar onaya sunulmasını talep etmiştir. Proje Yönetim Firması, İş Sahibinden gelen talebin haklılığını kontrol \\
& etmek için sözleşme eki marka listesine tekrar bakmış B markanın da marka listesinde yer aldığını, İş Sahibinin talep hakkının \\
& olduğunu doğrulamış ve İş Sahibinin B marka tercihini Yükleniciye iletmiştir. Yüklenici, kendisine iletilen bildirim üzerine A ve B \\
& seksiyonel kapı markaları arasında fiyat farkı olduğunu ileri sürerek iş emri değişikliği talebinde bulunmuştur
\end{tabular}

Talebin Yüklenici, ihale aşamasında verdiği teklifi A marka kapı fiyatlarını baz alarak verdiğini, bu sebeple İş Sahibinin B marka seksiyonel değerlendirilmesi: $\quad$ kapı tercih etmesi durumunda ilave fiyat farkının oluşacağını Proje Yönetim Firmasına yazılı olarak iletmiştir ve bu talebinde ısrarcı davranmıştır. Proje Yönetim Firması yaptığı değerlendirme sonucunda İş Sahibinin, sözleşme eki marka listesinde bulunan markalar arasında seçim tercihinin olduğunu, ihale sürecinde bu durumun da düşünülerek teklif verilmesi gerektiğini ve ihale dönemi verdiği teklifinde seksiyonel kapı fiyatının B marka için verildiğine dair bir ibare olmadığını Yükleniciye ileterek talebini reddetmiştir. Yüklenici her ne kadar inşai sürecin sonuna kadar talebini sürekli yenilese de talep kabul görmemiştir.

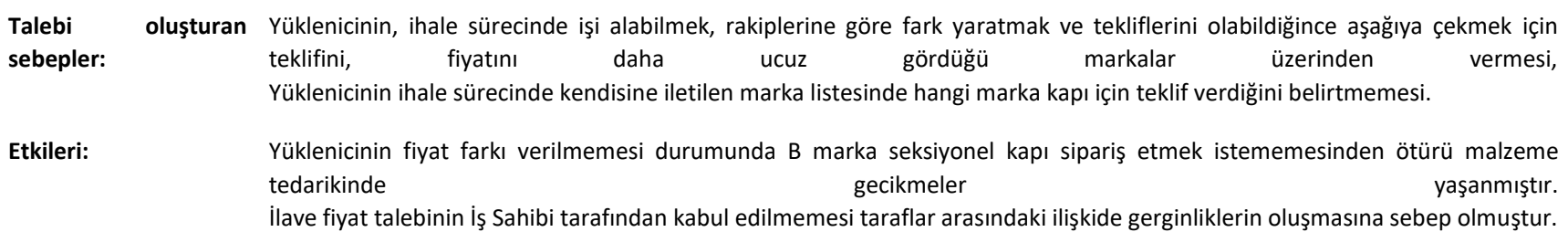

Pozitif yanı, Proje Yönetim Firmasına iletilecek, onaya sunulacak çalışmaların bilgi, belge ve dokümantasyonlarına son derece hâkim olması ve iletilen çalışmaların şeklen doğru olmasından ötürü Proje Yönetim Firmasının Yükleniciyi eğitmek ve gelen çalışmaları formata uygun tekrar düzenlemek zorunda kalmamasıdır. Negatif yanı ise, Yüklenicinin uygulama sırasında kendi açısından uygun gördüğü teknik düzeltme ve değişiklikleri zaman zaman onaya sunmadan uygulamaya çalışmasıdır. İşveren ile sık sık direkt iletişim halinde olmuş, Proje Yönetim Firmasının olmadığı ortamlarda görüşmeleri gerçekleştirmiştir.

Tasarım gruplarının tasarım sürecinde bir sürü revizyon ve çalışma yapmaları, gereğinden fazla yorulmaları ve çalıştı̆̆ süreyi karşılayacak revizyon bedellerini işverenden alamamaları projeye inşaat aşamasında destek vermemelerinde etkili olmuştur. Projede sürekli karar değişikliklerinin olması, gelgitlerin yaşanması ve işveren ihtiyaç planının netleşmemesinden ötürü tasarımlarda disiplinler arası uyumsuzluklar ortaya çıkmıştır.

\section{Proje bütçesine etkisi}

İş emri değişikliği talepleri projedeki en büyük etkisini proje bütçesi üzerinde göstermiştir. Örnek projede çokça yaşanan iş değişikliği taleplerinin proje bütçesi üzerinde yarattığı etkinin nicel analizi aşağıdaki şekildedir:

Sözleşme bedeli 49.500.000 TL 'dir. Yüklenicinin projenin inşai süresi boyunca Proje Yönetim Firmasına ilettiği tüm iş emri değişikliği taleplerinin toplam bedeli 14.000.000 TL'dir.

Yüklenicinin projenin inşai süresi boyunca proje yönetim firmasına ilettiği iş emri değişikliği taleplerinden, işin sonunda onaylanan ve tüm taraflarca anlaşmaya varılan toplam bedeli 8.000.000 TL'dir. İş değişikliklerden kaynaklı proje bütçesi artış1, sözleşme bedelinin yaklaşı \% $\% 15$ 'i olduğu görülmüştür. Örnek projenin gizlilik anlaşması olmasından ötürü çok detaylı bilgi verilemese de yapılan analiz sonucunda örnek projede yaşanan iş değiş̧ikliklerinin $\% 65$ 'inin işveren, $\% 25$ 'inin proje yönetim firması ve tasarım grubu, \%10'unun da yüklenici kaynaklı tespit edilmiştir (Şekil 3).

Elde edilen sonuçlara göre Yüklenicinin diğerlerine oranla daha az iş değişikliğine sebep olduğu görünse de proje boyunca ilettiği haksız talepler, proje katılımcıları arasında gerginliklerin oluşmasına, krizlerin yaşanmasına, projenin motivasyonun düşmesine dolaylı görünmeyen kayıpların oluşmasına sebep olmuştur. 
Tablo 2. Örnek projede yașanan iș değişikliklerinin proje bütçesi üzerindeki etkisi

\begin{tabular}{|c|c|c|c|c|c|}
\hline İşin Adi & $\begin{array}{l}\text { Proje Başlangıcında } \\
\text { Sözleşme Fiyati }\end{array}$ & $\begin{array}{l}\text { İş Emri Değişikliğinden } \\
\text { Doğan Ek Maaliyet }\end{array}$ & Proje Sonu Proje Maliyeti & $\begin{array}{l}\text { İş Emri Değişikliği } \\
\text { Içerisindeki Oranı }\end{array}$ & $\begin{array}{l}\text { Her İşin Kendi Sözleşme } \\
\text { Bedeli İçerisindeki Artiş } \\
\text { Orani }\end{array}$ \\
\hline Elektrik Işleri & 10.448.692,31 TI & $3.000 .000,00 \mathrm{Tl}$ & 13.448.692,31 TI & $40 \%$ & $29 \%$ \\
\hline Mekanik Işleri & 7.120.153,85 TI & $2.175 .000,00 \mathrm{TI}$ & $9.295 .153,85 \mathrm{TI}$ & $29 \%$ & $31 \%$ \\
\hline Toplam Tutar & 49.500.000,00 Tl & 7.500.000,00 Tl & $57.000 .000,00 \mathrm{Tl}$ & & \\
\hline
\end{tabular}

İş emri değişikliklerinden kaynaklı bütçe artışının \%31'ini mimari ve inşaat, \%40'sini elektrik, \%29'unu da mekanik işler oluşturmaktadır (Şekil 4, 5). İş emri değişikliklerinden kaynaklı elektrik işleri sözleşme bedelinde $\% 29$, mekanik işleri sözleşme bedelinde \%31 inşaat-mimari işler sözleşme bedelinde \%7 artış olmuştur (Tablo 2).

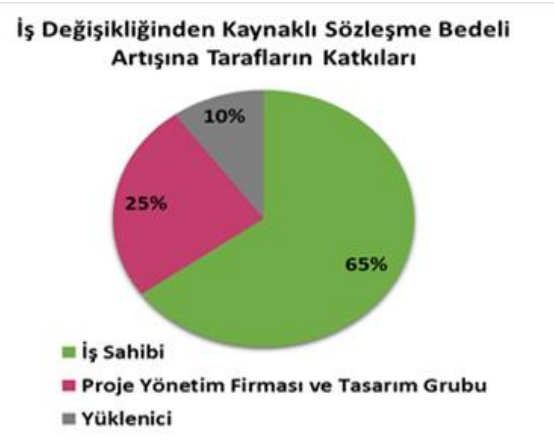

Şekil 3. Örnek projede yaşanan iş değişikliği emirlerine tarafların katkıları.

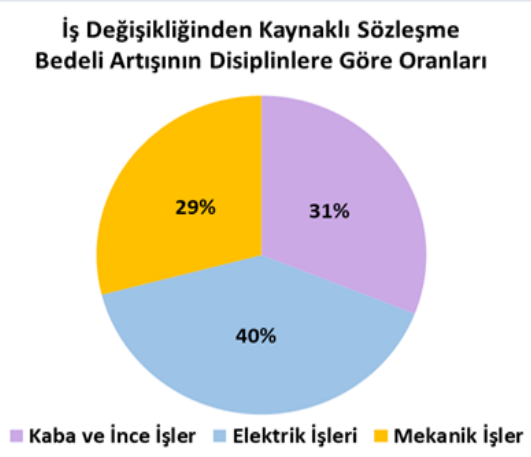

Şekil 4. İş değişikliği emirlerinden kaynaklı bütçe artışına tarafların katkıs

\section{Proje süresine etkisi}

İş emri değişikliklerinin ikinci en büyük etkisi proje süresi üzerinde olmuştur. Örnek projede çokça yaşanan iş değişikliği taleplerinin proje süresinde yarattığ 1 etkinin nicel analizi şu şekildedir:

Yüklenicinin sözleşmede taahhüt ettiği iş bitirme süresi süresi 360 gündür. Fakat, yüklenicinin 169 gün ilave süre talebi olmuştur. İlave süre talebinde gerekçe olarak aşağıdaki maddeler sunulmuştur:

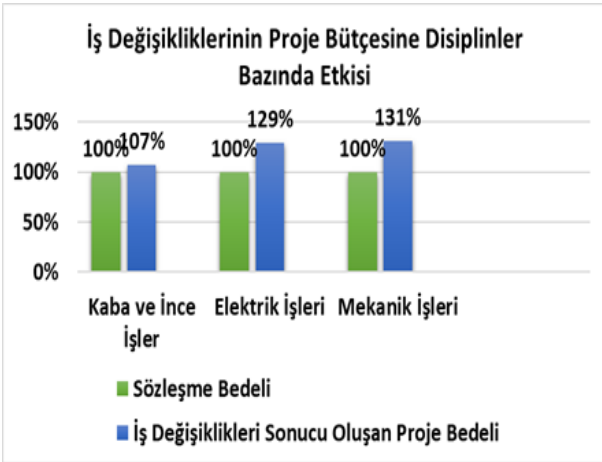

Şekil 5. İş değișikliği emirlerinin proje bütçesine disiplinler bazında etkisi

- İş Sahibinin projedeki yoğun revizyon taleplerinin mevcut işleri ve iş programını etkilemesi

- İş Sahibinin sözleşme kapsamında olmayan ilave iş taleplerinin mevcut işleri ve iş programını etkilemesi

- İş Sahibinin yetkililerin s1k sik saha denetimine gelmesi ve saha denetimi yapılan günlerde çalışmaların yavaşlaması

- İş Sahibinin malzeme onayları konusunda kararını geç iletmesinden dolayı bazı malzemelerin tedarik sürelerinin uzaması, uygulamada gecikmelere yol açması ve iş programını etkilemesi

- Yüklenicinin yağışlı günlerde imalat yapamamasından ötürü mücbir sebep kapsamında talep ettiği ilave iş süresi

Yüklenicinin ilave süre talebi proje yönetim firması tarafından incelenmiş olup 70 gün süre uzatımı verilmiştir. Uyuşmazlıklarda, gecikmeler ve süre uzatımı talepleri önem taşımaktadır. Özellikle gecikmelerin sınıflandırılması, süre uzatımı açısından hangi yöntemin uygulanacağını da belirleyebilecektir. Gecikmeler, kabul edilebilir (tazmin edilebilir ve edilemez), kabul edilemez ve eş zamanlı olarak üç temel başlıkta incelenir. Gecikmelerin analiz edilebilmesi, kabul edilebilir ve edilemez gecikmelerin ayıklanması, eş zamanlı gecikmelerde tarafların sorumluluk oranlarının belirlenmesi kritik yolun gösterildiği şebeke tabanlı ve detaylı bir iş programı ile mümkündür. Gecikme analizi için planlanangerçekleşen, etkilenen-planlanan, bozulan-gerçekleşen, net etki, bütüncül etki, zaman etki analizi gibi farklı yöntemler kullanılmaktadır $[13,14]$. Bu çalışmada zaman etki analizi yöntemi kullanılmış, işveren ve yüklenici kaynaklı gecikmeler arasındaki net fark bulunarak kusur işveren ile yüklenici 
arasında paylaştırılmıştır. Proje yönetim firması süre uzatımı konusundaki değerlendirmesini yaparken, ilave işlerin ve proje revizyonlarının genel hatları ile iş programının kritik hatları üzerinde veya paralel faaliyet olup olmama durumuna; malzeme onaylarının onaya geliş tarihi ve onaylanan tarihlerine; yağışların sözleşme şartları gereği mücbir sebep kapsamına girecek şiddette olup olmama durumuna ve saha denetimi yapılan günlerin tarihlerine bakarak kararını sonuçlandırmıştır. İş değişikliklerinin makaleye konu proje süresi üzerindeki etkisi Tablo 3 'ta gösterilmiştir.

\section{İş gücü verimliliğine etkisi}

İnşaat sürecinde yaşanan iş değişikliklerinin kendisi, etkisi ve yönetimi sırasında yaşanan sıkıntılar, Yüklenici çalışanlarının iş gücü verimliliğini etkilemiştir. Sürecin iş gücü verimliliği ile olan ilişkisi şu şekilde özetlenebilir:

- $\quad$ Ek işlerin ödemelerinin ve onay süreçlerinin çok uzaması, yaptığ 1 işin bedelini alamayan Yüklenicinin çalışma motivasyonunu düşürmüş, daha isteksiz çalışmasına sebep olmuş ve sonuç olarak iş gücü verimliliğinde azalma olmuştur.

Tablo 3. Örnek projede yaşanan iş değișikliklerinin proje süresi üzerindeki etkisi.

\begin{tabular}{ccc} 
Süre Uzarım Talebinin Gerekçesi & $\begin{array}{c}\text { Talep Edilen Ek } \\
\text { Süre }\end{array}$ & Proje Yönetim Firması Değerlendirmesi \\
\hline
\end{tabular}

İş Sahibi Yetkilileri tarafından yapılan saha denetimlerinden dolayı çalışılamayan 8 gün günler
İs Sahibi Yetkililerinin yılın belli günlerinde bu tarz saha denetimleri yapacağı ve bu günlerde çalışma yapılamayacağı

denetimleri yapacağı ve bu günlerde çalışma yapılamayacağı
sözleşme öncesinde Yükleniciye bildirilmiş olup, taahhüt ettiği sözleşme süresinin içerisinde olduğu kabul edilmiştir.

\author{
Meteorolojik durum raporuna göre \\ bölgede ortalama 4 yıllık yağış \\ miktarından daha fazla yağış olması 11 gün \\ nedeniyle sahada çalışma yapılamayan \\ günler
}

Mekanik ve elektrik tesisatı işlerinde $\begin{array}{llrl}\text { inşaat sürecinde meydana gelen } & \\ \text { revizyonlardan ötürü yaşanan süre } & 100 \text { gün }\end{array}$ kayıları

İnşai ve mimari işlerde inşaat sürecinde meydana gelen revizyonlardan ötürü 20 gün yaşanan süre kayıpları
Sözleşmede mücbir sebepler başlığı altında belirtilen "bölgedeki ortalama son 10 yıllık yağış miktarından daha fazla yağış olması" ibaresi mücbir sebep olma koşulunu 0 gün sağladığından ötürü "son 4 yıllık ortalama yağış" mücbir sebep olarak değerlendirilemez.

İlave işlerin ve proje revizyonlarının genel hatları ile iş programının kritik hatları üzerinde veya diğer işler ile paralel faaliyet olup olmama durumuna göre değerlendirilmiştir. 65 gün Mekanik ve elektrik işlerin aynı periyotta devam edebileceği birbiri üzerinde engel yaratmayacağı görülmektedir.

İlave işlerin ve proje revizyonlarının genel hatları ile iş programının kritik hatları üzerinde veya paralel faaliyet olup olmama durumuna değerlendirilmiştir. Mekanik ve elektrik işlerin süresinin çok uzamasından ve farklı mahallerde gerçekleşecek çalışmalar olmasından ötürü paralel faaliyet içerisinde kalmaktadır

Malzemelerin onaya sunulma tarihleri ve onaylanan tarihleri tespit edilerek gecikme yapılan malzemeler için yeni tedarik sürelerine bakılmıştır. Mekanik ve elektrik imalatlarının da 5 gün süresinin uzamasından ötürü, verilmesi düşünülen ek sürenin bir kısmı paralel faaliyet içerisinde kalmıştır.

\section{0 gün} Malzeme onaylarına geç dönülmesinden
kaynaklı tedarik süresinde yaşanan 30 gün
ötelenmeler

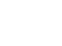

- $\quad$ İş sahibinin bazı taleplerini geç iletmesi, yapılan birtakım işlerin bozulmasına, kırılmasına ve yeniden yapılmasına neden olmuş, tekrar tekrar aynı işi yapan çalışanların çalışma motivasyonunu düşürmüş ve sonuç olarak iş gücü verimliliğinde azalma olmuştur.

- S S S S S likla yapılan ilave iş ve değişikliklerden kaynaklı olarak iş programının planlananın çok üstünde ötelenmesi, Yüklenicinin işin istenilen şekilde tamamlanmasına yönelik inancını bitirmiş ve sonuç olarak iş gücü verimliliğinde azalma olmuştur.

- $\quad$ Normal süreç boyunca yüklenici, yapılan imalatın sahada uygulanabilirliğine ve değer mühendisliği yapılmasına yönelik birçok öneride bulunmuştur. Ancak iş değişikliklerinin çok sık ve yoğun iletilmeye başlaması yükleniciyi bunaltmış ve yeni yapılan işler için uygulamaya yönelik önerileri kesilmiştir. Yüklenicinin çalışma motivasyonunu düşürmüş, daha isteksiz çalışmasına sebep olmuş ve sonuç olarak iş gücü verimliliğinde azalma olmuştur.

\section{Proje paydaşları arasındaki ikili ilişkilere etkisi}

İş değişikliklerinin en önemli etkilerinden biri de proje paydaşları arasındaki ikili ilişkilerde gerginliklere ve bu gerginliklerin zaman zaman krizlere dönüşmesine sebep olmasıdır. Örnek projede yaşanan iş emri değişikliği taleplerinin oluşum sebeplerine bağlı olarak, ikili ilişkiler üzerindeki etkileri vaka analizlerinde örnekler bazında gösterilmiş olup sürecin ikili ilişkiler ile olan bağlantısı şu şekilde özetlenebilir: 
- İş sahibi vekillerinin sorumluluk almak istememesinden ötürü yüklenicinin imalata başlayabilmesi için ön onay alması gereken iş emri değişikliği çalışmalarına dönüş alamamas1 ve bekletilmesi,

- $\quad$ İş sahibinin bazı taleplerini geç iletmesi, yapılan birtakım işlerin bozulmasına, kırılmasına ve yeniden yapılmasına neden olmuş, yüklenicinin tekrar tekrar aynı işi yapmas1

- $\quad$ İş sahibinin yükleniciden sözlü olarak talep ettiği iş değişikliklerini, yazılı belge olmamasından ötürü reddetmesi,

- Yüklenicinin iş değişikliklerinden kaynaklı kayıplarını başka yollardan telafi etmeye çalışması yüklenici ve iş sahibi arasında büyük krizlerin yaşanmasına sebep olmuştur.

Sözleşme hazırlanırken, Türkiye'de yapılan en büyük hatalardan birisi, bu makale yazarlarının gerek eğitim yaşamlarında gerekse de inşaat söktürende gözlemledikleri üzere, sözleşmenin bir bütün olarak ele alınmaması, sözleşmenin farklı belgelerden oluşan bir bütün olduğunun anlaşılamamasıdır. Bu bakımdan sözleşme ve eklerinin bir bütün olduğu, aslında şartnamelerin, proje tasarım çizimlerinin, kimi durumlarda sözleşme eki olarak belirtilen bazı standartların bizzat sözleşmenin kendisi gibi değerlendirilmesi gerektiğinin ne kadar önemli olduğu ve uyuşmazlıklara yol açabileceği bu çalışmada da görülmüştür. Sözleşme hazırlanırken, sözleşme ana metni ve eklerin bir hiyerarşi içinde sözleşmenin sonunda zikredilmesi, bu hiyerarşiye göre uyuşmazlıkların belirlenmesi tüm taraflar açısından gereklidir. Konuyla ilgili bir örnek verilmesi açıklayıcı olacaktır. İncelenen projede bir vakada, yüklenici, sözleşme eki elektrik ve mekanik projelerin esas alındığı hesap raporlarının yanlış olduğunu, e-hesapların yeniden yapılarak elektrik projelerinin hazırlanması gerektiğini, bu revizyonlardan dolayı oluşan ilave bedelin de kendilerine ödenmesi gerektiğini beyan etmiştir. Talebini, sözleşme eki zeyilname olan 'Sözleşme Dışı İşler', dokümanında yer alan maddeye atıfta bulunarak iletmiştir. Sözleşmede konuyla ilgili madde, Borçlar Kanunu genel hükümleriyle uyumlu olarak aşağıda yazıldığı gibidir:

' Yüklenici kendisine teslim edilen İş Yeri'nin nitelik itibariyle inşaata elverişli olup olmadı̆̆ını, zemin yapısını, Uygulama Projeleri ile uyumunu araştırmak durumundadır. Plan ve Uygulama Projeleri Işs Sahibi tarafindan verilmiş olsa bile, sorumlu bir meslek adamı ve basiretli tacir olarak Iş'i yapmayı üstlenen Yüklenici, bu kabulüyle kendisine verilen Uygulama Projeleri başta olmak üzere tüm Sözleşme Ekleri ve teknik belgelerin Iş Yeri'nin gereklerine, teknik ve sanat kurallarına uygun olduğunu kabul etmiş ve sorumluluğu üstlenmiş saytlır."

Fakat sözleşme eki zeyilname içerisinde yer alan 'Sözleşme Dışı İşler' ' başlığı altında da aşağıdaki ifade yer almaktadır:

''Teknik hesap raporlarının hatasından kaynaklı her türlü değişiklik kapsam dişındadır",

İş Sahibi, Anahtar Teslimi İnşaat İşleri Sözleşme yapıldığını ileri sürerek gelen talebi reddetmiştir ve Proje Yönetim Firmasından değerlendirme istemiştir. Talebin değerlendirilmesi sürecinde İş Sahibi konuyu kriz haline getirse de Yüklenicinin ilave bedel talebi sözleşme ekinde yazılan madde gereği kabul edilmiş olup, sözleşme ve ekleri arasındaki hiyerarşinin belirtilmemesinin iş sahibi açısından yarattığı sorun açısından son derece çarpıcı bir örnektir.

\section{Hak Talebi Dokümanlarının Kontrol Edilmesi}

Proje sürecinde meydana gelen değişikliklerin sahada uygulanmaya başlanmadan önce değişikliğin incelenmesini ve değerlendirilmesini gerektiren prosedür süreçlerinin tamamlanması gerekir [12]. Normalde, yüklenici öncelikli olarak iş sahibi ve proje yönetim firması tarafından kendisine iletilen, sözleşme eki projeler ve dokumanlar ile uygulama projeleri ve talepler arasında oluşan değişiklikleri tespit etmelidir. Revizyonlar ve ilave işler ile ilgili değişikliğe ait fiyat farkını ve talep gerekçesini gösteren iş değişikliği emri talep formunu uygulama ve imalatı yapmadan önce proje yönetim firması onayına sunmalıdır. Ancak, örnek projede zaman zaman iş sahibi ve yüklenicinin direkt birbirleri ile iletişime geçmesinden ve iş sahibinin bu görüşmelerde yükleniciden yazılı olmayan değişiklik taleplerinde bulunmasından ötürü, yüklenici sürecin başında iş değişikliği emri taleplerini proje yönetim firması onayına iletmeden sahada birtakım imalatları yapmıştır. Proje yönetim firmasının durumu fark etmesi üzerine yükleniciyi uyarması sonrasında yüklenici iş değişikliği emri talep çalışmalarını proje yönetim firmasının onayına sunmaya başlamıştır. Bu durum hak talebi oluşumuna verilebilecek sadece bir örnektir ve örnek sayısı daha da arttırılabilir. İşlerin yoğunluğu ve zaman baskısı nedeniyle gözden kaçması çok muhtemel olan iş değişikliği emri onaylarının ve dolayısı ile oluşacak hak taleplerinin sistematik yönetilebilmesi için kontrol adımları ve tabloları oluşturulmuştur. Örnek olması açısından kontrol tabloları içi doldurularak aşağıda kontrol adımlarını takiben sunulmuştur.

Yüklenici tarafından onaya sunulan iş değişikliği formunun proje yönetim firması tarafından kontrolünün prosedür süreci şu şekildedir:

1. Taleplerin istenilen formatta gelmesi,

2. Gelen taleplerin sözleşme dokümanlarına göre kontrol edilmesi (Şekil 6),

3. Sözleşme kapsamında olmayan taleplerin değerlendirmeye alınması, kapsamda olanların ise reddedilmesi (Şekil 7),

4. Taleplerdeki birim fiyatların kontrolü (Şekil 8),

i. Sözleşme eki birim fiyatlarla kontrolü,

ii. Yeni birim fiyatların analizlerinin kontrolü,

a. Enterpolasyon,

b. Proforma fatura kontrolü,

c. Piyasa teklifleri ile kontrolü, 


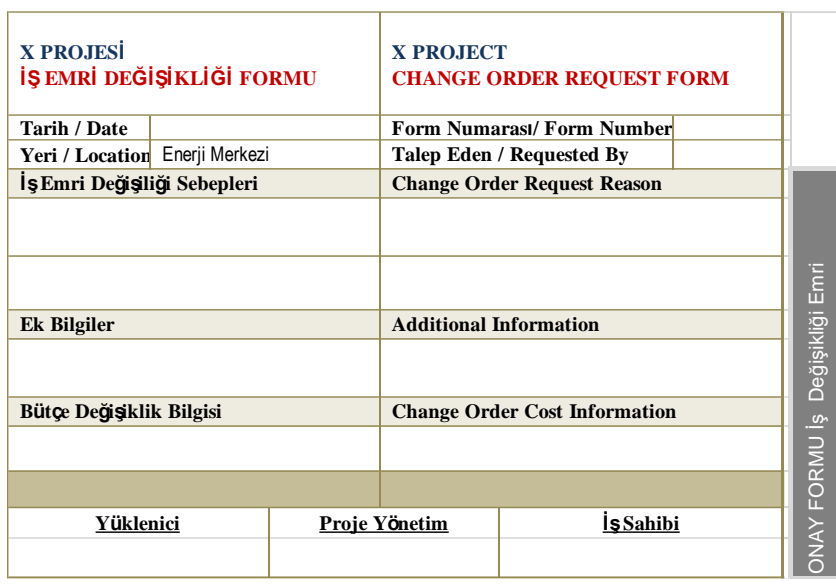

Şekil 6. İş değişikliği emri kapak sayfası.

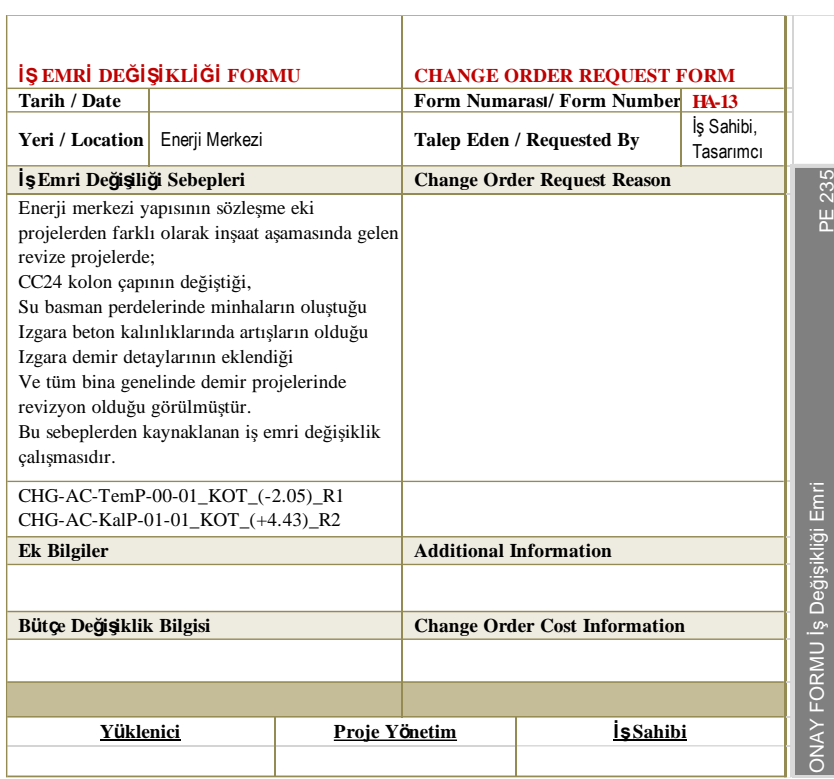

Şekil 7: Taleplerin sözleşme dokümanlarına göre kontrol edilmesi.

\begin{tabular}{|c|c|c|c|}
\hline \multicolumn{4}{|c|}{ 1-4/K'-M ARASI YÖNETI M Bİ NASI KABA YAPI İŞLEI RI Nİ N YAPILMASI } \\
\hline Performed Work & Poz No. & Un. Price & Un. \\
\hline Yapılan İş & Poz Nu. & Br. Fiyat & Br. \\
\hline \multicolumn{4}{|c|}{ 1-4/K'-M ARASI YÖNETIM BİNASI KABA YAPI İŞLEIRINININ YAPILMASI } \\
\hline Drenaj İşleri, $150 \mathrm{~mm} * 2 \mathrm{ad}$ & & $80,00 \mathrm{TL}$ & $\mathrm{m}$ \\
\hline $\begin{array}{l}\text { Makine İle Her Derinlikte Yumuşak ve Sert Toprağın } \\
2 \text { Kazılmas1, Nakliyesi }\end{array}$ & & $18,00 \mathrm{TL}$ & $\mathrm{m}^{3}$ \\
\hline Dolgu ve Sıkıştırma İşleri & & $40,00 \mathrm{TL}$ & $\mathrm{m}^{3}$ \\
\hline C16 Beton (Grobeton), Dolgu İșleri & 3004 & $20,85 \mathrm{TL}$ & $\mathrm{m}^{2}$ \\
\hline C16 Beton (Grobeton), Temel Altı Çalsşma & 3004 & $20,85 \mathrm{TL}$ & $\mathrm{m}^{2}$ \\
\hline C35 Yapisal Beton & 3006 & $235,00 \mathrm{TL}$ & $\mathrm{m}^{3}$ \\
\hline Her Türlü Beton ve Betonarme Kalıbı & 3002 & $50,00 \mathrm{TL}$ & $\mathrm{m}^{2}$ \\
\hline Nervürlü Donatı Çeliği & 3008 & $3.500,00 \mathrm{TL}$ & ton \\
\hline Temel Altı yalıtım İşleri (Membran) & INSSS. YBF.01 & $42,30 \mathrm{TL}$ & $\mathrm{m}^{2}$ \\
\hline Perde yalıtım İșleri (Sürme+Xps+levha) & INSS. YBF.02 & $81,30 \mathrm{TL}$ & $\mathrm{m}^{2}$ \\
\hline Su Tutucu Şişen Bant & İNŞ. YBF.03 & $43,78 \mathrm{TL}$ & mtül \\
\hline Bask1 Profili & İNŞ. YBF.04 & $8,25 \mathrm{TL}$ & mtül \\
\hline Koruma Betonu (5 CM) & & $208,50 \mathrm{TL}$ & $\mathrm{m}^{3}$ \\
\hline Topraklama İşleri & & & \\
\hline
\end{tabular}

Şekil 8: Taleplerdeki birim fiyatların kontrolü.

5. İş kalemi miktarlarının kontrolü (Şekil 10),

i. Azalan, eksilen miktarların kontrolü, ii. Artan, yeni eklenen miktarların kontrolü

\begin{tabular}{|c|c|c|c|c|c|}
\hline \multicolumn{6}{|c|}{ YENi Bí Rí M Fí YAT ANALIZZi } \\
\hline İmalatın Cinsi & Temel Altı Su Yalttımı (2 kat 3mm Membran) & & & & \\
\hline Ölçü Birimi & $\mathrm{m} 2$ & & & & \\
\hline Birim Fiyat No & YBF-İNŞ-01 & & & & \\
\hline & $\underline{\text { ACIKLAMA }}$ & Birimi & Miktarı & $\begin{array}{l}\text { Birim } \\
\text { Fiyatı }\end{array}$ & Tutarı \\
\hline & $\begin{array}{l}\text { Cift kat elastımerik esaslı } 3 \mathrm{~mm} \text { polyester keçe taşıyııılı } \\
\text { membran }\end{array}$ & $\mathrm{m} 2$ & 2,20 & $12,10 £$ & 26,62 £ \\
\hline & Geotekstil keçe (250 gr/m2) & $\mathrm{m} 2$ & 1,05 & $1,48 \mathrm{E}$ & $1,55 \mathrm{E}$ \\
\hline & Membran Uygulama İşciliğgii & $\mathrm{m} 2$ & 2,3 & 3,69 も & 8,48 ‡ \\
\hline & Keçe Uygulama İşçiliğii & $\mathrm{m} 2$ & 1,05 & 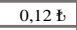 & 0,13 £ \\
\hline & ARA TOPLAM & & & & 36,79 ६ \\
\hline & KAR & $\%$ & $15 \%$ & 36,79 £ & $5,52 \mathrm{f}$ \\
\hline & GENEL TOPLAM & & & & 42,30 є \\
\hline $\begin{array}{l}\text { Birim Fiyat } \\
\text { Tarifi }\end{array}$ & & & & & \\
\hline $\begin{array}{l}\text { Teknik şartnamel } \\
\text { edevat, iş̧ilik,yat } \\
\text { belirtilen iş güve } \\
\text { harcama ile yükl } \\
\text { KURUŞ dir. }\end{array}$ & 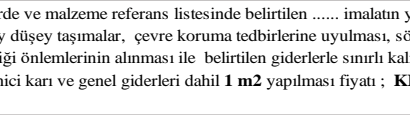 & $\begin{array}{l}\text { pilmass i } \\
\text { leşme ek } \\
\text { amak ka } \\
\mathbf{2} \mathbf{K} \mathbf{K} \mathbf{~}\end{array}$ & $\begin{array}{l}\text { için her tü } \\
\text { i iș güven } \\
\text { yydyla yap } \\
\text { TÜRK Lí }\end{array}$ & $\begin{array}{l}\text { ü makine, } \\
\text { ji şartname } \\
\text { acak her tür } \\
\text { ASI OTU2 }\end{array}$ & $\begin{array}{l}\text { alet } \\
\text { lerinde } \\
\text { llü } \\
\mathrm{Z}\end{array}$ \\
\hline Ölçü & & & & & \\
\hline Proje üzerinden 1 & saplanarak ödeme yapillr. & & & & \\
\hline Malzeme Mark: & & & & & \\
\hline YÜKLENICI & PROJE YÖNETIM FIRMASI & & & Анїіві & \\
\hline
\end{tabular}

Şekil 9: Yeni birim fiyatların analizlerinin kontrolü

IMALATIN ADI : ALTYAPI/ KAZI İȘLERi

\begin{tabular}{|c|c|c|c|c|c|c|c|c|}
\hline \multicolumn{9}{|l|}{ IMAL } \\
\hline AÇIKLAMA & BíRím & BENZER & ADET & EN & BOY & YÜKSEKLIKK & ALAN & $\begin{array}{l}\text { TOPLAM } \\
\text { MIKTAR }\end{array}$ \\
\hline \multicolumn{9}{|c|}{ REVIZE PROJE } \\
\hline \multicolumn{9}{|c|}{ ATIKSU BACA KAZISI } \\
\hline R1A & $\mathrm{m} 3$ & & & & & 1,75 & 3,14 & 5,50 \\
\hline R2A & $\mathrm{m} 3$ & & & & & 2,15 & 3,14 & 6,75 \\
\hline CHGIA & $\mathrm{m} 3$ & & & & & 2,35 & 3,14 & 7,38 \\
\hline CHG2A & $\mathrm{m} 3$ & & & & & 2,85 & 3,14 & 8,95 \\
\hline $\mathrm{R} 3 \mathrm{~A}$ & $\mathrm{~m} 3$ & & & & & 2,15 & 3,14 & 6,75 \\
\hline \multicolumn{9}{|c|}{ SÖZLESME EKÍ } \\
\hline \multicolumn{2}{|c|}{ ATIKSU BACA KAZISI } & & & & & & & 0,00 \\
\hline CHG1A & $\mathrm{m} 3$ & & & & & 3,15 & 3,14 & $-9,89$ \\
\hline $\mathrm{CHG} 2 \mathrm{~A}$ & $\mathrm{~m} 3$ & & & & & 3,55 & 3,14 & $-11,15$ \\
\hline CHG3A & $\mathrm{m} 3$ & & & & & 3,80 & 3,14 & $-11,93$ \\
\hline CHG4A & $\mathrm{m} 3$ & & & & & 4,05 & 3,14 & $-12,72$ \\
\hline CHG5A & $\mathrm{m} 3$ & & & & & 4,30 & 3,14 & $-13,50$ \\
\hline
\end{tabular}

Şekil 10: Azalan ve artan iş miktarlarının kontrolü.

6. Tutarların hesaplanması, kontrolü (Şekil 11),

i. $\quad$ Fark tutarların kontrolü

L-M / 4-5 AKSLARI ARASI MAHAL REVIZYONU

\begin{tabular}{|c|c|c|c|c|c|}
\hline Performed Work & Poz No. & Un. Price & Un. & $\begin{array}{r}\text { AMOUNT, } \\
\text { Difference }\end{array}$ & $\begin{array}{r}\text { CoST, } \\
\text { Increase/Decrease }\end{array}$ \\
\hline Yapılan Iş & Poz Nu. & Br. Fiyat & Br. & $\begin{array}{r}\text { Mi KTAR, } \\
\text { Fark }\end{array}$ & $\begin{array}{r}\text { TUTAR, } \\
\text { Artıș/Azaliş }\end{array}$ \\
\hline \multicolumn{6}{|l|}{ L-M / 4-5 AKSLARI ARASI MAHAL REVIZYYONU } \\
\hline $\begin{array}{l}\text { Makine İle Her Derinlikte Yumuşak ve Sert } \\
\text { Toprağın } 2 \text { Kazılması, Nakliyesi }\end{array}$ & 2004 & $18,00 \mathrm{TL}$ & $\mathrm{m}^{3}$ & 257,026 & $4.626,47 \mathrm{TL}$ \\
\hline Dolgu ve Sıkıștırma İșleri & & $40,00 \mathrm{TL}$ & $\mathrm{m}^{3}$ & 861,006 & $34.440,24 \mathrm{TL}$ \\
\hline C16 Beton (Grobeton) Temel Altı & 3004 & $20,85 \mathrm{TL}$ & $\mathrm{m}^{2}$ & 99,715 & $2.079,06 \mathrm{TL}$ \\
\hline C35 Yapisal Beton & 3006 & $235,00 \mathrm{TL}$ & $\mathrm{m}^{3}$ & 132,207 & $31.068,65 \mathrm{TL}$ \\
\hline Her Türlü Beton ve Betonarme Kalıbı & 3002 & $50,00 \mathrm{TL}$ & $\mathrm{m}^{2}$ & 863,647 & $43.182,35 \mathrm{TL}$ \\
\hline Nervürlü Donatı Çeliği & 3008 & $3.500,00 \mathrm{TL}$ & ton & 24,131 & $84.458,50 \mathrm{TL}$ \\
\hline Temel Altı yalıtım İşleri & & $16,00 \mathrm{TL}$ & $\mathrm{m}^{2}$ & 257,183 & $4.114,93 \mathrm{TL}$ \\
\hline Yapsal Çelik işleri & & $7.250,00 \mathrm{TL}$ & ton & 1,267 & 9.185,75 TL \\
\hline Kompozit Döşeme & HE_YBF_32 & $117,89 \mathrm{TL}$ & $\mathrm{m}^{2}$ & $-303,620$ & $-35.794,44 \mathrm{TL}$ \\
\hline Yüzey Sertleştirici Şap - $10 \mathrm{~cm}$ (Üst Döşeme) & & $38,40 \mathrm{TL}$ & $\mathrm{m}^{2}$ & 596,520 & $22.906,37 \mathrm{TL}$ \\
\hline Çatı $4 \mathrm{~cm}$ Taşyünü Panel Kaplama & & $120,00 \mathrm{TL}$ & $\mathrm{m}^{2}$ & 319,48 & $38.337,60 \mathrm{TL}$ \\
\hline TOPLAM / TOTAL & & & & & $238.605,46 \mathrm{TL}$ \\
\hline
\end{tabular}

Şekil 11: Fark tutarın hesaplanması.

\section{Sonuç ve Öneriler}

Son yıllarda dünyada yatırımcıların kendilerini güvende hissedecek ortamda inşaat yatırımı yapmak istemeleri ve 
projelerin sözleşmelerce belirlenen süre, kalite ve maliyette gerçekleştirilmesi talepleri çok paydaşlı ve kompleks yapıdaki inşaat projelerinin çok daha iyi yönetilmesi gerekliliğini doğurmuştur. $\mathrm{Bu}$ sebeple proje yönetim firmaları artık inşaat projelerinde sıklıkla karşımıza çıkan bir paydaş konumuna gelmiştir. Ancak, proje yönetim firmalarının yönetim performanslarını birinci dereceden etkileyen önemli iki unsur bulunmaktadır: iş değişikliği emirleri ve hak talepleri. Projelerde ortaya çıkan iş değişikliği emirlerinin projenin kalitesi, süresi, verimlilik, taraflar arası ilişkiler gibi konularda büyük etkilerinin olduğu gözlemlenmiştir. Buna ek olarak hak taleplerinin kontrolü ve yönetimi konusunda da bir sistemden bahsetmek zordur. Proje sürecinde oluşan konulara yönelik kararların hızlı ve efektif alınması, projenin başarısında kilit rol oynar $[15,16]$. Bu çalışmada inşaat projeleri boyunca oluşan iş değişikliği emirleri ve bunların bir sonucu olarak doğan hak taleplerinin hızlı ve doğru yönetilebilmesi için öncelikle iş değişikliği emirlerinin yönetim sürecindeki aksamalar sunulmuş ve sistematik bir iş değişikliği ve hak talebi kontrolü sağlanması amacıyla kontrol adımları ve formları oluşturulmuştur. Kontrol adımlarının ve tablolarının oluşturulabilmesi için ise örnek bir proje üzerinden vaka analizleri yapılarak proje yönetim organizasyonu, yaşanan iş değişiklikleri ve hak talebi sebepleri, etkileri ve aksayan yönleri detaylı olarak irdelemiştir.

$\mathrm{Bu}$ çalışmadaki en önemli sonuçlardan birisi de uyuşmazlıkların büyük ölçüde mal sahibi ile yüklenici arasında imzalanan sözleşmeden kaynaklanmasıdır. Bu husus, sözleşme hazırlanma sürecinin ne kadar önemli olduğunun, inşaat proje yönetiminde temel başliklardan birisi olan sözleşme idaresinin tasarım öncesi ve tasarım evresindeki iş başlıklarının ne kadar önemle ele alınması gerektiğini göstermektedir.

İnşaat projelerinde yüklenici üzerindeki süre, maliyet ve kalite baskısının yanında sektörün rekabetçiliği de göz önüne alındığında bu çok paydaşlı ve dış etmenlere oldukça açık sektörde, iş değişikliği taleplerinin çok olması ve dolayısı ile bolca hak talebi doğması normaldir. $\mathrm{Bu}$ iş değişikliği emirlerinin ve hak taleplerinin hızlı, doğru ve sistematik yönetilebilmesi için izlenmesi gereken adımların bilinmesi, bu adımların her bir iş değişikliğinde ve hak talebinde atlanmadan takip edilmesi büyük önem arz etmektedir. Bu sebeple çalışma kapsamında sunmuş olduğumuz iş değişikliği ve hak talebi kontrol adımlarının ve tablolarının kullanılması günümüzde hemen her projede karşılaşılan sorunların baş göstermesini engelleyecek ya da doğru yönetilebilmesi adına sektördeki profesyonellere yardımcı olacaktır.

\section{Etik kurul onayı ve çıkar çatışması beyanı}

Hazırlanan makalede etik kurul izni alınmasına gerek yoktur.

Hazırlanan makalede herhangi bir kişi/kurum ile çıkar çatışması bulunmamaktadır.

\section{Kaynaklar}

[1] İNTES, Türkiye İnşaat Sanayicileri İşveren Sendikası, İnşaat Sektörü Raporu, 2020.

[2] Staiti M, Othman M, Jaaron AA. Impact of change orders in construction sector in the West Bank. InInternational conference on industrial engineering and operations management 2016, pp. 1690-1698.

[3] Hao, Qi, Weiming Shen, Joseph Neelamkavil, and Russ Thomas. "Change management in construction projects." In Proceedings of International conference on information technology in construction. 2008.

[4] Bakr, G.A. Studying the Status of Variations in Construction Contracts in Jordan. In Computing in Civil and Building Engineering 2014, pp. 187-194.

[5] CMAA, Construction Management Association of America, Standard CM Services and Practice. 2nd Edn., 1993, Reston, VA.

[6] Lavigne, Joseph C. Construction Contract claims and methods of avoiding contract litigation through dispute resolution alternatives. Florida Univ Gainesville, 1993.

[7] Levin, Paul. "Construction contract claims, changes \& dispute resolution." American Society of Civil Engineers, 1998.

[8] Nahod M.M., RadujkovicM. Procedures For Change Management İ The Realizition Phase Of Construction Projecest. Association of Researchers in Construction Management Conference, 2011, pp. 859-868.No. 10.

[9] PRM, (2005). The Project Resource Manual, The Construction Specifications Institute, Mc Graw-Hill Companies Inc, New York.

[10] Migliaccio, Giovanni C., Len Holm. Introduction to construction project engineering, 2018. Routledge.

[11] VT, Virginia 2020 , https://it.vt.edu/projects/project_management/integrated changecontrol.html

[12] O’Brien, J.J., Construction Change Orders. 1998. McGraw Hill, New York.

[13] Trauner, T. J. Construction delays: Understanding them clearly, analyzing them correctly. 2009. ButterworthHeinemann, Oxford, UK.

[14] Bordoli, D. W., Baldwin, A. N. A methodology for assessing construction project delays. Construction Management \& Economics, 1998, 16(3), 327-337.

[15] Sanvido, V., K. Parfitt, M. Guvensia and M. Coyle, Critical success factors for construction projects. J. Constr. Eng. M. ASCE, 1992, 118(1): 94-111.

[16] Gray, C., Hughes W., Building Design Management. 2001. Butterworth Heinemann, Oxford, UK. 